
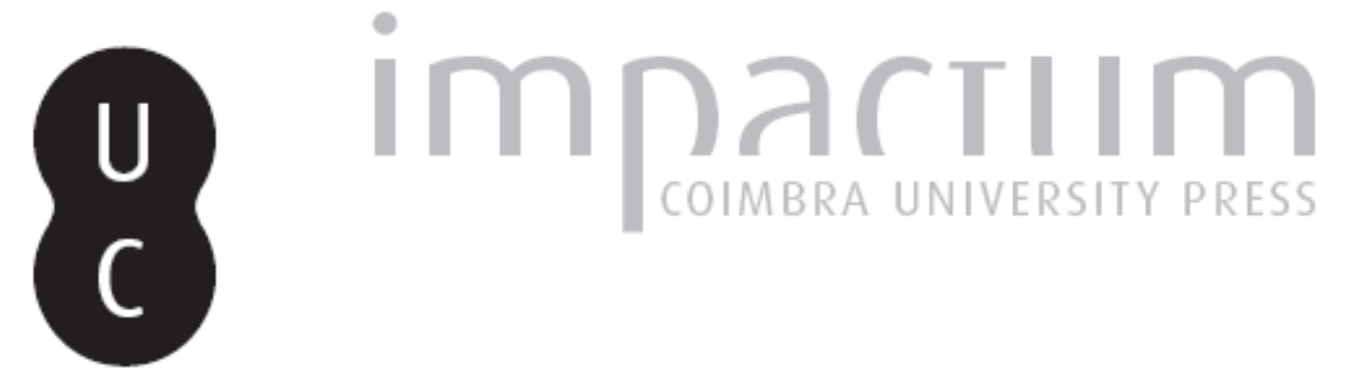

\title{
Os grandes incêndios florestais registados em 1993 na fachada costeira ocidental de Portugal Continental
}

\author{
Autor(es): $\quad$ Lourenço, Luciano; Nunes, Adélia; Rebelo, Fernando \\ Publicado por: Associação Portuguesa de Riscos, Prevenção e Segurança \\ URL \\ persistente: \\ URI:http://hdl.handle.net/10316.2/40191 \\ DOI: \\ DOl:https://doi.org/10.14195/1647-7723_1_5 \\ Accessed : $\quad$ 26-Apr-2023 08:18:28
}

A navegação consulta e descarregamento dos títulos inseridos nas Bibliotecas Digitais UC Digitalis, UC Pombalina e UC Impactum, pressupõem a aceitação plena e sem reservas dos Termos e Condições de Uso destas Bibliotecas Digitais, disponíveis em https://digitalis.uc.pt/pt-pt/termos.

Conforme exposto nos referidos Termos e Condições de Uso, o descarregamento de títulos de acesso restrito requer uma licença válida de autorização devendo o utilizador aceder ao(s) documento(s) a partir de um endereço de IP da instituição detentora da supramencionada licença.

Ao utilizador é apenas permitido o descarregamento para uso pessoal, pelo que o emprego do(s) título(s) descarregado(s) para outro fim, designadamente comercial, carece de autorização do respetivo autor ou editor da obra.

Na medida em que todas as obras da UC Digitalis se encontram protegidas pelo Código do Direito de Autor e Direitos Conexos e demais legislação aplicável, toda a cópia, parcial ou total, deste documento, nos casos em que é legalmente admitida, deverá conter ou fazer-se acompanhar por este aviso.

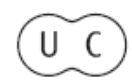




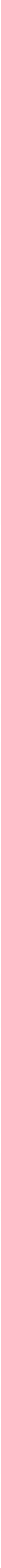




\title{
Os grandes incêndios florestais registados em 1993 na fachada costeira ocidental de Portugal Continental
}

\author{
Luciano Lourenço * \\ Adélia Nunes ** \\ Fernando Rebelo ***
}

\begin{abstract}
Resumo:
A “época de fogos" de 1993 revestiu-se de condiçơes especiais que permitiram o desenvolvimento de grandes incêndios florestais na orla costeira ocidental, onde são pouco frequentes. Os fogos importantes ocorreram numa única sequência climática, a qual levou ao progressivo agravamento do risco do incêndio. Geograficamente, distribuíram-se por áreas situadas na Região Centro e no Algarve.

Palavras chave:
\end{abstract}

Incêndios florestais, índice de risco, Regiăo Centro, Algarve.

Résumé:

“L’époque des incendies" a présentée en 1993 des conditions particulières qui ont permis le développement de grands incendies de forêt dans la bordure de la côte occidentale où ils sont peu fréquents. Les incendies les plus importants se sont développés dans une seule séquence climatique, laquelle a fini par le progressif aggravement du risque d'incendie. Géographiquemente ils se sont distribués par des aires situées dans la Region Centre et l'Algarve.

Mots clés:

Incendies de forêt, indice de risque, Region Centre, Algarve

Abstract:

The "fire season" of 1993 had special conditions that contributed to the development of (big) forest fires in the occidental coast, where they are less frequent. The most important fires occured in only one climatic sequence, which lead to the progressive increase of fire risk, that geographically were distributed by a few areas, one in the central area of the country and the other one in Algarve.

Key Words:

Forest fires, risk rate, Central Portugal, Algarve.

\section{Introdução}

O Verão de 1993 foi, mais uma vez, marcado por grandes incêndios florestais. Como também vem sendo hábito, alguns deles ocorreram na Região Centro, na área correspondente à Delegação Florestal da Beira Litoral. Embora tratando-se de um fenómeno habitual, este ano de 1993 revestiu-se de certos aspectos particulares, na medida em que dois desses grandes incêndios percorreram áreas litorais, o que é extremamente raro. Além disso, não constituiram caso único, pois igualmente na faixa ocidental do litoral algarvio ocorreram mais três grandes incêndios florestais.

Nestas circunstâncias, ter-se-ão verificado condições especiais, as quais, em nossa opinião,

\footnotetext{
* Assistente convidado. Instituto de Estudos Geográficos. Faculdade de Letras. Universidade de Coimbra.

** Professora Estagiária do Ensino Secundário.

*** Professor Catedrático. Instituto de Estudos Geográficos. Faculdade de Letras. Universidade de Coimbra.
}

merecem ser analisadas. Deste modo, decidimos averiguar não só as razões da sua deflagração, mas também e sobretudo procurámos encontrar a justificação para a progressão destes fogos e para a incineração de tantos hectares, em áreas onde, à partida, parece não se justificar a existência de grandes incêndios florestais.

Com efeito, tratava-se de áreas litorais, de modo geral aplanadas (à excepção do caso da Serra da Boa Viagem), com uma carga de combustível relativamente baixa, distribuída com muita irregularidade, tanto horizontal como verticalmente, ecom descontinuidades em ambas as direcções, mas tratava-se, também, de Perímetros Públicos e Áreas de Paisagem Protegida, onde, além de se poderem implantar algumas medidas de combate que normalmente são mais difíceis de aplicar em áreas privadas, tais como os contra-fogos, era possível conjugar os esforços dos Corpos de Bombeiros com os dos técnicos e trabalhadores do Instituto Florestal e do Instituto de Conservação da Natureza, no sentido de rapidamente se debelarem as chamas. 
Como tal não aconteceu, têm de se admitir circunstâncias anormais que permitiram o desenvolvimento dos fogos. Entendemos, pois, que importa anal isar cientificamente estas circunstâncias para, se possível, evitar que, no futuro, se repitam.

Deste modo, começaremos por efectuar uma análise ao modo como decorreu a progressão dos fogos, para depois, em função das condições físicas em que se desenvolveram, verificarmos se, naquelas circunstâncias, o combate era mais difícil ou mesmo impossível.

Por último, em função das análises efectuadas, retiraremos os "ensinamentos" que estes incêndios florestais nos quiseram transmitir.

Propositadamente, para não alongar demasiado este artigo, não consideraremos os múltiplos efeitos queo fogo provocou não só doponto de vista económico, mas sobretudo nos aspectos social, ambiental e do património construído, tendo em conta a especificidade destas matas como áreas de lazer e, no caso de algumas delas, de protecção dunar.

Por uma questão de proximidade, acompanhámos mais de perto os incêndios do Centro Litoral, pelo que dispomos de maior quantidade de elementos para analisar.

Deste modo, estes merecerão um estudo mais exaustivo do que os registados no Algarve, os quais, por falta de trabalho de campo, não poderão ser analisados tão minuciosamente. Apesar deste facto, não quisemos deixar de os mencionar.

\section{Os incêndios do Centro Litoral}

Sensivelmente coincidentes no tempo e geograficamente não muito distantes, registaram-se dois focos de incêndio no Centro Litoral, os quais viriam a evoluir de tal modo que se tornariam em dois dos três incêndios mais importantes na área da Delegação Florestal da Beira Litoral, no ano de 1993.

O primeiro deles deflagrou e desenvolveu-se numa área aplanada, constituída essencialmente por dunas, enquanto que o segundo percorreu uma área mais acidentada, correspondente à Serra da Boa Viagem, ambas as áreas consideradas de grande potencialidade turística (F. Rebelo, L. CUNHA e A.C. Almeida, 1990).

\section{Fogo das Dunas de Mira/Cantanhede/Quiaios}

Este incêndio foi detectado às 23:45 h do dia 19 de Julho de 1993, junto à lixeira municipal de Mira, que na altura se encontrava em combustão, tendo sido dado como extinto no dia 24 .

Lavrou durante 88 horas e 12 minutos, tendo percorrido 6802 ha, distribuídos pelos concelhos de Mira, Cantanhede e Figueira da Foz, respectivamente com 159,6; 3014,7 e 3627,7 hectares percorridos pelo fogo (Fig. 1), sendo, na quase totalidade, de pinheiro bravo (Pinus pinaster).

A protecção inadequada da lixeira e o vento forte, com velocidade superior a $30 \mathrm{~km} / \mathrm{h}$, que se fez sentir no litoral ao longo de toda a tarde do dia 19 de Julho, terão sido os principais responsáveis pelo transporte de partículas incandescentes, as quais, posteriormente, terão pegado fogo à mata. Porém, este fogo foi imediatamente combatido pelo pessoal da ex-Administração Florestal de Mira e pelos Bombeiros Voluntários de Mira, vindo a ser considerado extinto pelas duas horas da manhã seguinte.

No entanto, passadas algumas horas, na tarde do dia 20 de Julho, às 13:45 h, o Centro de Prevenção e Deteç̧ão de Incêndios Florestais da Lousã (C05) foi informado de que o incêndio das Dunas de Mira se tinha reacendido, atingindo desde o seu reinício proporções alarmantes. Ainda não eram 17:00 h e já as chamas progrediam nas Dunas de Cantanhede, depois de terem queimado parte do pinhal das Dunas de Mira, tendo varrido em cerca de três horas mais de 4 quilómetros de extensão.

Pelas 20:00 h, a frente do fogo apresentava uma configuração alongada em direcção a SSE, com vários quilómetros de comprimento. Nesta fase, tendo em conta a distância percorrida e a hora do seu início, pode estimar-se uma velocidade de propagação do incêndio de cerca de $1 \mathrm{~km}$ por hora, para a qual muito terão contribuído os ventos fortes que continuavam a soprar de Norte.

Por volta dessa mesma hora, deflagrava um novo foco de incêndio, a Sul da estrada da Caniceira, enquanto que, junto à lagoa dos Almadouros, lavrava a grande velocidade outra frente com origem noutro foco que terá eclodido pelas 19:00 h desse mesmo dia.

O aparecimento destes focos de incêndio secundários, muito provavelmente, ter-se-á ficado a dever à projecção de material incandescente transportado pelo vento, o qual terá provocado novos reacendimentos.

Apesar de à noite se ter verificado um certo afrouxamento na velocidade do vento, o incêndio das Dunas continuou a desenvolver-se com certa intensidade, pois cerca das $23: 30 \mathrm{~h}$ podiam ser identificadas três frentes principais. Uma delas, cuja progressão tivera início no foco situado junto da lixeira, lavrava nas proximidadesdo Cantodos Coelhos. Originárias dos focos localizados a Sul da Estrada da Caniceira, lavravam duas frentes, a mais intensa, entre a Estrada da Caniceira e a Estrada dos Estreitos, e a outra, entre a Tocha e as Berlengas, num local situado sensivelmente a Norte.

Nas primeiras horas da madrugada do dia 21, o rumo do vento manteve-se de NNW, não de forma 


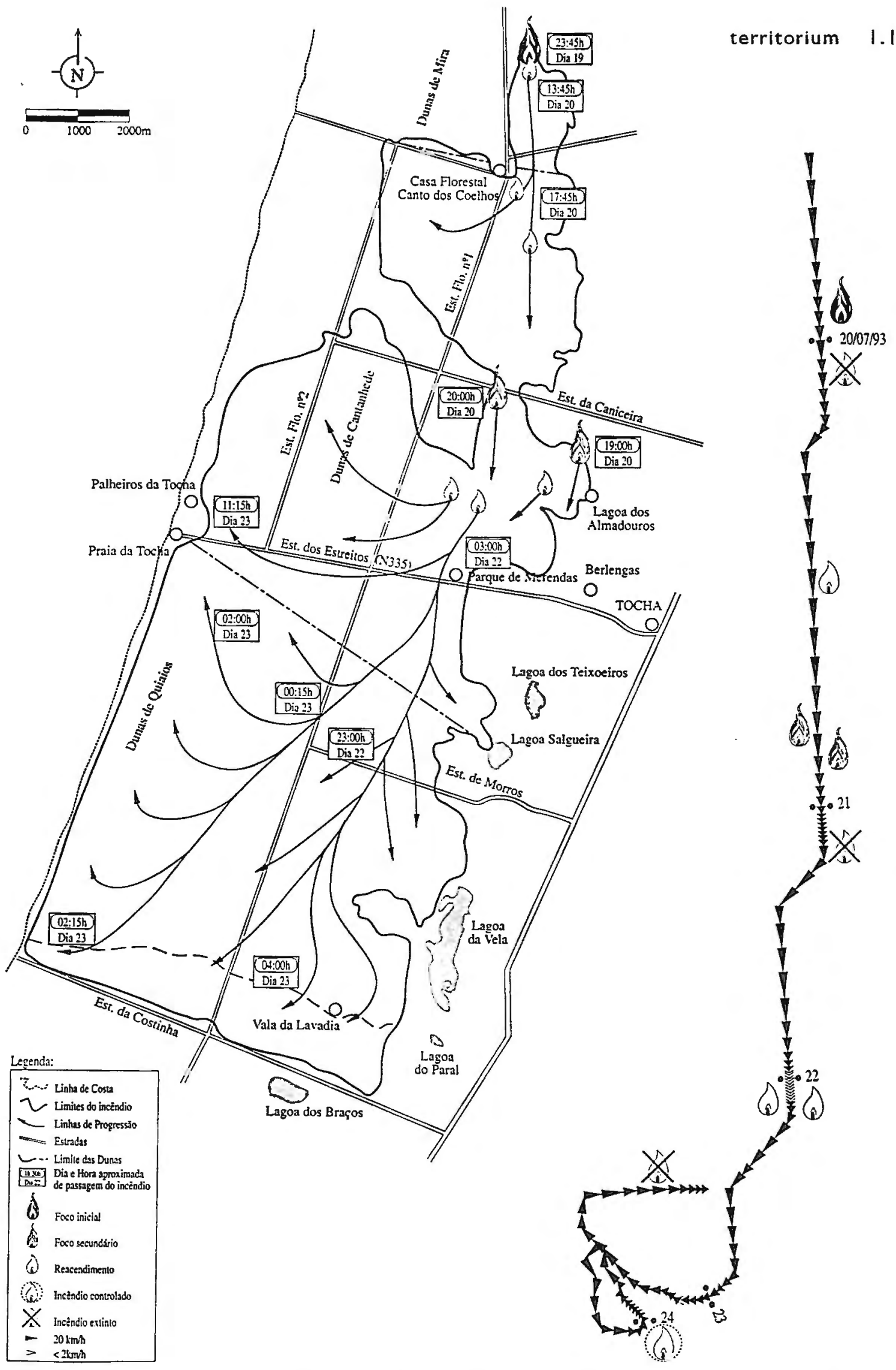

Fig. 1 - Esboço simplificado da progressão do fogo nas Dunas de Mira/Cantanhede/Quiaios e diagrama da evolução do vento em Monte Real. 
tão intensa, tendo possibilitado um ataque mais eficaz às chamas e levando à extinção do incêndio pelas 8:00 $\mathrm{h}$ da manhã.

No entanto, apesar do incêndio ser dado como extinto, continuaram a deflagrar pequenos focos de incêndio, os quais não foram prontamente combatidos. $\mathrm{Na}$ manhã do dia 22 verificou-se uma alteração no rumo dos ventos; a direcção predominante de Norte foi substituida, temporariamente, por ventos do quadrante Este, os quais foram responsáveis não só por um aumento importante dos valores da temperatura ao longo do dia, mas também por um decréscimo do valor minimo da humidade relativa do ar.

Assim, a conjugação destes factores terá provocado, ao longo da manhã e da tarde, fortes reacendimentos, pois, pelas 15:00 h ardiam com alguma intensidade duas frentes nas Dunas de Cantanhede. Uma delas, progredia junto ao Parque de Merendas da Estrada Tocha-Praia da Tocha, e a outra, junto ao Canto dos Coelhos, mais a Norte.

Demodogeral, a progressãodo incêndio continuou a fazer-se para Sul e foi quase junto do local onde estava instalado o Comando Operacional (Parque das Berlengas) que o fogo, progredindo por copas, passou a Estrada Nacional $n^{\circ}$ 335-1, Tocha-Praia da Tocha. Apesar de esta passagem se ter efectuado pela transposição de uma faixa com cerca de $30 \mathrm{~m}$ de largura, esta circunstância não foi aproveitada para controlar o incêndio, pelo que o fogo continuou a avançar em direcção às Dunas de Quiaios.

Depois de as alcançar, cruzou a estrada que liga a povoação de Morros à Estrada Florestal ${ }^{\circ} 1$, quando eram aproximadamente 23:00 h. Tendo em conta a distância percorrida desde a Estrada $n^{0} 335-1$ e o tempo gasto nesse percurso, pode calcular-se que a velocidade de propagação do fogo, teria sido de aprox imadamente $460 \mathrm{~m} / \mathrm{h}$.

Entretanto, nas Dunas de Cantanhede e também na Estrada Florestal $n^{\circ} 1$, no troço compreendido entre aEstrada ${ }^{\circ} 335$ e o Canto dos Coelhos, encontravase pessoal de modo a impedir que o incêndio que vinha progredindo para poente, devido à alteração dorumo do vento, cruzasse esse caminho e consumisse as florestas aí existentes, pois até então a sua configuração resumia-se, grosso modo, a uma larga faixa a Este desta ligação.

Contudo, não decorreu muito tempo atéo incêndio cruzar esse caminho florestal. Seriam aproximadamente 00.15 h do dia 23, quando o fogo transpôs a Estrada $\mathbf{n}^{\circ} 1$, nas Dunas de Quiaios, a Norte da Estrada dos Morros, com duas direcções preferenciais, NW e SW, devido aos ventos fortes que sopravam de leste. Por esta altura, o incêndio atingiu proporções assustadoras, varrendo a grande velocidade a parte ocidental das Dunas de Quiaios, pois pelas 02:15 h passou a Vala da Lavadia, entre a Estrada Florestal $\mathrm{n}^{\circ} 1$ e a praia. Considerando-se a distância percorrida, supõe-se que o fogo terá atingido uma velocidade aproximada de $2,5 \mathrm{~km} / \mathrm{h}$, diminuindo, posteriormente, a sua marcha devastadora; chegou à Estrada da Costinha por volta das $03: 30 \mathrm{~h}$. Com esta velocidade de progressão, o controlo das chamas já era muito díficil. No entanto, antes, não teria sido possível evitar esta situação?

Por outro lado, entre a Estrada Florestal $n^{\circ} 1$ e a Lagoa da Vela desenvolvia-se uma frente cuja velocidade de progressão era menor, pois passou a Vala da Lavadia cerca das 04:00 h da manhã. Se tivermos em conta que, pelas $11: 00 \mathrm{~h}$ do dia anterior, o incêndio se encontrava junto à Estrada de Morros e só às 4:00 h da manhã seguinte é que cruzou a Vala da Lavadia, poderemos estimar que a velocidade de propagação, na parte leste do Caminho Florestal $n^{\circ} 1$, seria de cerca de $660 \mathrm{~m} / \mathrm{h}$.

Entretanto, a Norte, nas Dunas de Cantanhede, o incêndio ainda não tinha passado a Estrada Florestal $n^{\circ} 1$, continuando a arder junto à Casa Florestal de Morros, na Costinha, mas uma frente que vinha de Quiaios, aproximava-se cada vez mais de Praia da Tocha.

Porém, nas Dunas de Cantanhede, cerca das 10:45 h, uma frente de grande intensidade dirigia-se para a Praia da Tocha, obedecendo mais uma vez ao rumo do vento que era de ESE.

Não demorou muito para que a Praia da Tocha se encontrasse praticamente cercada de fogo, em resultado da aproximação tanto da frente que vinha de Quiaios, a qual se aproximava cada vez mais do Parque de Campismo, como da outra que, tendo ultrapassado a Estrada Florestal $n^{\circ} 2$, se dirigia para Oeste.

Eram quase 11:15 h quando o fogo chegou a Praia de Tocha. Deste modo, cerca de duas horas mais tarde, podiam distinguir-se dois fogos diferentes nas Dunas de Cantanhede, um deles, perto da Praia da Tocha, e o outro, um pouco mais a Norte, no Palheirão. Quando eram 15 horas, oincêndio lavrava já muito próximo das casas da Praia da Tocha.

Ao fim da tarde, registou-se nova inversão no rumo do vento, passando a soprar com uma componente claramente marítima, com base nos registos da estação meteorológica de Monte Real. Tal como aconteceu noutros grandes incêndios, também este fogo viria a ser controlado quando se verificou a entrada de ar com trajectooceânico, oqual teve como consequência o aumento da humidade relativa do ar e o decréscimo dos valores da temperatura, situação que possibilitou um controlo mais rápido do incêndio.

Assim, ao fim da tarde, este incêndio foi dado como controlado, subsistindo, contudo, pequenos focos, ao longo de toda a noite e ainda no dia seguinte, vindo a ser dado como extinto no dia $24 \mathrm{de}$ 
Julho, pelas $18 \mathrm{~h}$, procedendo-se posteriormente ao rescaldo e vigilância, que se prolongaram até ao dia seguinte.

\section{Incêndio da Serra da Boa Viagem}

$O$ alerta de que tinha deflagrado um incêndio no sopé setentrional da Serra da Boa Viagem foi dado pelas 20:25 h, do dia 20 de Julho de 1993.

A eclosão deste incêndio ocorreu no lugar designado por Barrocas (Fig. 2), situado próximo da estrada de Quiaios-Praia de Quiaios, correspondendo a uma área bastante acidentada, de difícil acesso, cujo coberto vegetal era constituído essencialmente por pinheiro bravo (Pinus pinaster), pinheiro manso (Pinus pinea), eucalipto (Eucaliptus globulus) e com o solo coberto por uma densa camada de manta morta. Estas condições podem imprimir grandes proporções ao fogo, logo desde o início, e dificultam o seu combate.

Deste modo, o incêndio começou por assumir um certo desenvolvimento, tendo continuado ao longo de toda a noite, embora com menor intensidade, não só devido à diminuição da velocidade do vento, mas também e sobretudo, devido à inexistência de um coberto vegetal denso e contínuo, poiseste alternava com terras de pasto e vinhas.

Todavia, na manhã do dia 21 , era possível distinguir duas frentes de chamas, uma, com maior intensidade, em direcção a Leste, enquanto a outra se dirigia, com menor velocidade, para a povoação da Murtinheira. A direcção preferencial para este ficou a dever-se aos ventos que sopravam intensamente de NNE e que, ao deflectirem na Serra, conferiram ao fogo uma configuração oval. Este incêndio viria a ser dado como extinto pelas 13:00 h desse mesmo dia, 21 de Julho.

Entretanto, antes disso, cerca da 1:00 h da manhã do dia 21, eclodia um novo foco de incêndio, mas agora na vertente oposta, no lugar de Monte Alto. A área queimada por este foco limitou-se a uns quantos metros quadrados.

Mais tarde, quando eram aproximadamente 16:00 $h$, este fogo reacendeu-se. Para o controlar recorreuse aos reforços que se encontravam em trabalho de vigília na encosta Norte, os quais foram imediatamente mobilizados para a vertente Sul a fim de combaterem o fogo que avançava a grande velocidade, o qual viria a ser dado como controlado às $18: 30 \mathrm{~h}$ e extinto às 20:00 h.

Como se demonstra pelas consequências que veio a originar, esta decisão deveria ter sido mais ponderada pois, sabendo-se que os reacendimentos são responsáveis pela maioria dos grande incêndios florestais, não nos parece que se devam abandonar os fogos logo depois de dados como extintos. Sabemos que os meios disponíveis são insuficientes e, muitas vezes, obrigam a tomar decisões que, não sendo as melhores, são as possíveis. Mas, não será já altura de, com base nestes exemplos, ponderar a actuação futura dos meios envolvidos, de modo a evitar situações destas?

Porque não se activam grupos especiais para efectuarem o rescaldo e a vigilância após o fogo? Embora previstos $\left(\mathrm{n}^{\circ} 2\right.$, do $\operatorname{art}^{\circ} 20^{\circ}$ do Decreto Regulamentar $n^{\circ} 55 / 81$, de 18 de Dezembro) não têm sido postos em prática. Não seria um modo eficaz de evitar não só a ocorrência de grande número de reacendimentos, mas também e sobretudoa incineração de milhares de hectares de floresta?

$\mathrm{Na}$ encosta Norte, a falta de vigilância e os ventos fortes terão possibilitado o reacendimento de vários focos, de tal modo que, quando eram $21: 00 \mathrm{~h}$, já o fogo atingiagrandes proporções, tendo continuado a lavrar na Serra durante toda a noite, progredindo com maior velocidade para Oeste, em direcção à povoação da Murtinheira.

Cerca das 12:00 h do dia 22, o fogo já se encontrava muito próximo da Murtinheira. Em contrapartida, a frente que se dirigia para Leste, fazia-o com menor velocidade em função do rumo do vento que lhe era contrário, pois soprava de Nordeste. Esta direcção geral do vento, a soprar de Leste, vem acentuar ainda mais as condições gerais para a rápida progressão do incêndio, pois, devido ao seu percurso continental, o vento torna-se mais seco e quente. A mudança do rumo do vento para Leste coincide com a entrada do incêndio na parte mais abrupta da Serra e de maiores declives, altura a partir da qual se tornou incontrolável, formando-se frentes em todas as direcções.

Uma delas, a mais intensa, lavrava a grande velocidade pela vertente ocidental da Serra, numa área bastante acidentada e de difícil acesso. Outra, dirigia-se para a Bandeira, tendo entrado no Prazo de $S^{\text {ta }}$. Marinha quando eram aproximadamente 15:30 h. Uma terceira frente, que se dirigia para ESE e progredia com menor intensidade, entrouno Perímetro Florestal cerca das 16:30 h.

Porém, outra alteração do rumo do vento, de novo para o quadrante Norte, acompanhada por aumento de velocidade, terá permitido que esta frente atingisse cada vez maiores proporções, pondo em perigo a Casa do Guarda Florestal cerca das 17:30 h.

Entretanto, foram efectuados pedidos de reforços para a área do restaurante da Vela (Chalêt), dado que o incêndio que lavrava na área planáltica se aproximava também a grande velocidade. OComando Operacional, que se tinha deslocado para aí, foi obrigado a abandonar o local pouco depois de se ter instalado, pois encontravase praticamente rodeado de fogo.

Com efeito, uma frente que vinha de Norte reuniu-se a outra que tinha deflagrado a Sul, um 
territorium 1.1994

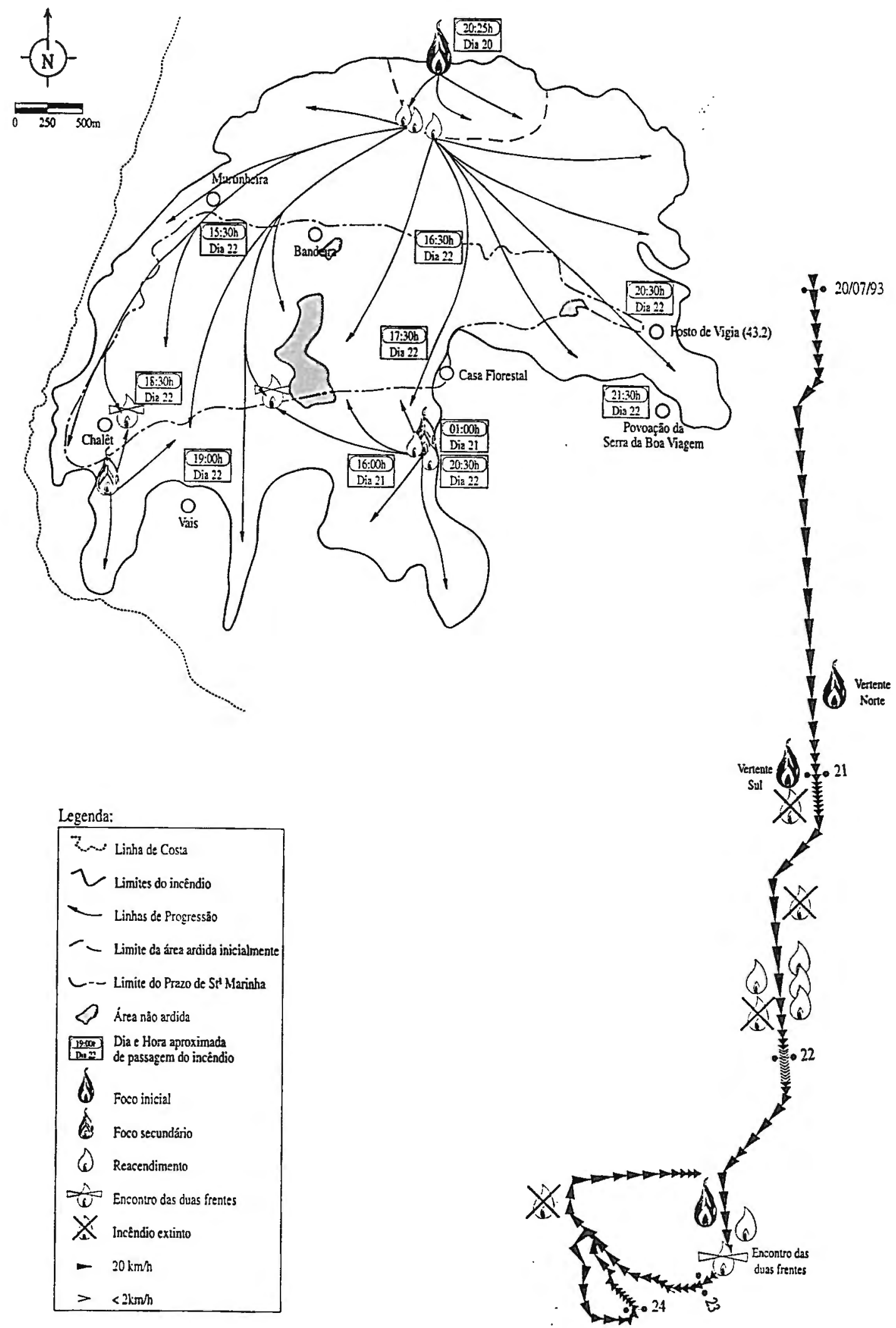

Fig. 2 - Esboço muito simplificado da progressão do fogo na Serra da Boa Viagem e diagrama da evolução do vento em Monte Real. 
pouco acima do complexo turístico do Vale do Leão, tendo-se verificado, nesta área, aquilo que é conhecido por "efeito de chamada" da frente de fogo sobre a outra que está próxima dela, o que funcionou como contra-fogo (Fig. 3). O Chalêt arderia entre as 18:30 e as 19:00 $\mathrm{h}$ (Fot. 1).

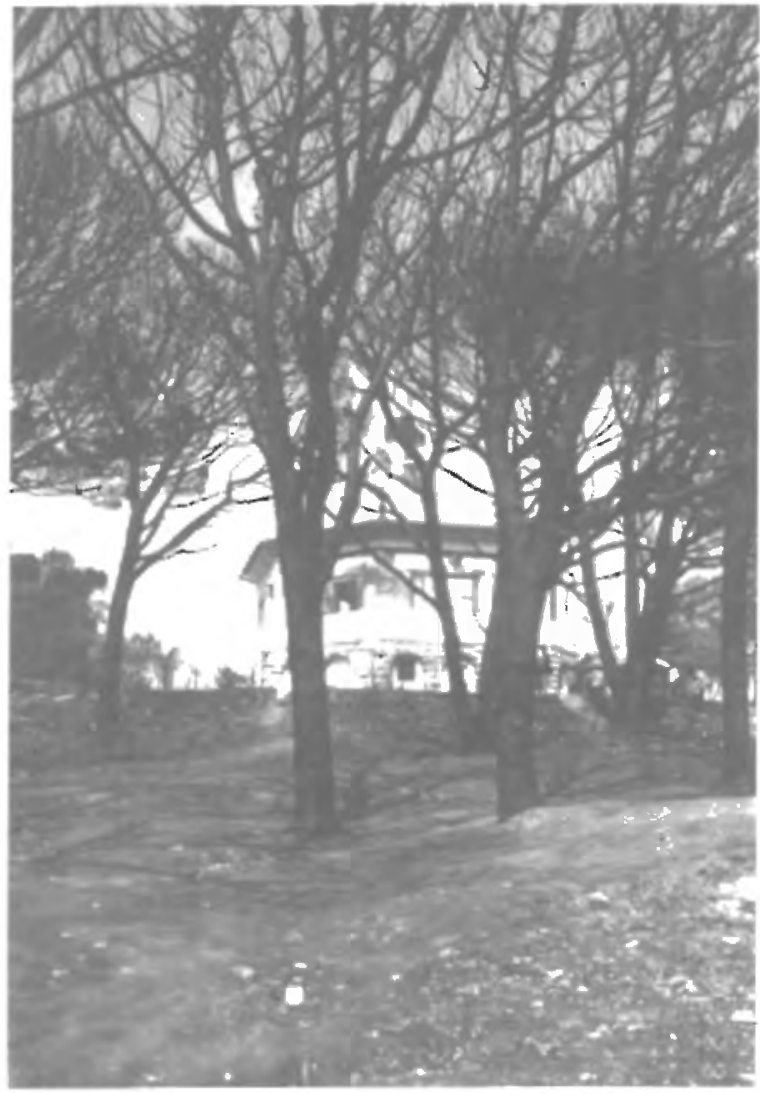

Fot. 1 - Alto da Vela (Serra da Boa Viagem). O Chalêt alguns dias após o incêndio.
Pelas 19:00 h, outra frente descia rapidamente a Serra dirigindo-se para a povoação de Vais, onde 7 casas foram consumidas pelas chamas.

Por seu turno, as frentes que lavravam na parte Leste da Serra da Boa Viagem atingiam também alguma intensidade, pois, cerca das $20: 30 \mathrm{~h}$, o vigia do Posto 43.2 foi obrigado a abandoná-lo, enquanto outra frente se dirigia para a povoação da Serra da Boa Viagem, tendo-se dela aproximado quando eram quase 21:30 h. Pelas 20:30 horas, ou devido a reacendimentos ou a eventual projecção de materiais incandescentes, deflagrou outro incêndio na área de Monte Alto, iniciando-se logo com grande velocidade de progressão, vindo a ligar-se ao que lavrava na área planáltica, tendo também funcionado, de algum modo, como contra-fogo final.

Nesta fase, o incêndio da Serra da Boa Viagem foi um fogo essencialmente de copas, varrendo grande parte dela em apenas algumas horas, continuando, contudo, nos dias seguintes, pois só viria a ser dado como extinto às $12: 00 \mathrm{~h}$ do dia 24 de Julho.

Deste modo, durante 71 horas e 35 minutos, entre os dias 20 e 24 de Julho de 1993, foram percorridos pelo fogo 1173,5 ha de floresta da Serra da Boa Viagem, no concelho da Figueira da Foz.

\section{Condições físicas responsáveis pelo desenvolvimento dos fogos do Centro Litoral}

\section{Orografia}

Os fogos florestais que deflagraram nas Dunas e na Serra da Boa Viagem percorreram formas de relevo completamente diferentes.

Por um lado, aquele que afectou os Perímetros Florestais das Dunas de Mira/Cantanhede/Quiaios desenvolveu-se por uma área com características topográficas semelhantes entre si, caracterizada por

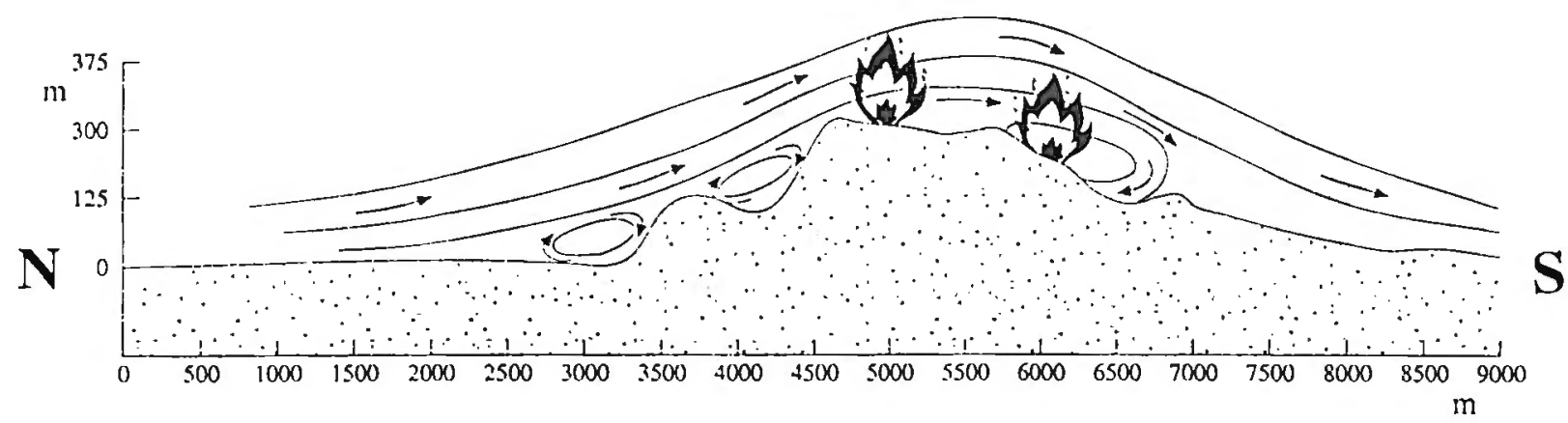

Fig. 3 - Representação esquemática do efeito da circulaçăo atmosférica local no encontro das duas frentes de chamas, no cimo da Serra da Boa Viagem, nas imediaçōes do Chalêt. 
uma certa monotonia das formas. Trata-se de um rele vo constituído por dunas, apresentando ligeiras ondulações de baixa altitude. A cota média acima do nível do mar é da ordem dos $20 \mathrm{~m}$. As dunas mais altas apresentam altitudes máximas de cerca de $30 \mathrm{~m}$ e urna disposição geral perpendicular à linha de costa, com orientação W-E.

No entanto, apesar da aparente uniformidade que caracteriza a área, quando se desce ao pormenor, podem diferenciar-se três unidades morfológicas neste sistema dunar: "as dunas propriamente ditas, as depressões interdúnicas e as superfícies planas" (A. Campar de Almeida, 1990, p. 153). Desde a duna primária, paralela à costa, até à linha das lagoas passa-se por uma faixa estreita de dunas irregulares, parabólicas, com uma orientação dominante de W-E aNW-SE, e pelas dunas dominantes, aparentemente oblíquas, de direcção geral W-E, sem dúvida as mais altas (A. CAMpar DE Almeida, 1990).

Por seu turno, a Serra da Boa Viagem constitui o único relevo saliente a destacar nesta vasta costa, essencialmente, constituída por areias. Com um comprimento de cerca de sete quilómetros e uma orientação geral NW-SE, a Serra apresenta-se como um relevo bastante acidentado relativamente ao seu tamanho. De ocidente para oriente, destacamos os seguintes pontosmais elevados: Vela (202m), Bandeira (258 m), Monte Redondo (226 m), Cumieira (186 m) e Boa Viagem (194 m). Por outro lado, desenvolvemse vales extremamente profundos e complexos, de orientação W-E, a Norte, e N-S, a Sul .

O flanco Norte, em contacto com os relevos baixos e aplanados das dunas, apresenta-se bastante abrupto, constituindo uma verdadeira barreira aos ventos que ao longo do litoral sopram de quadrante Norte (NW a NE), enquanto que a vertente Sul é muito mais suave, nela destacando-se numerosas lombas que descem ao encontro das terras baixas.

\section{Cobertura vegetal}

Assementeirase plantações nas Dunas de Quiaios tiveram início em 1926 e terminaram em 1940. Nas Dunas de Mira, as primeiras sementeiras de pinheiro bravo fizeram-se no ano de 1918, mas so em 10 de Fevereiro de 1919 foi aprovado um projecto de arborização, referente à sementeira de 2062 ha, cujos trabalhos tiveram início nesse mesmo ano (M. A. REI, 1924). A arborização de toda esta superficíe foi dada como concluída em 1943.

Para a sementeira de pinheiro bravo (Pinus pinaster), experimentou-se uma mistura de semente de estorno com a de penisco, pois aquela espécie fixando rapidamente as areias, devido à sua facilidade de crescimento, constituiria um óptimo abrigo aos pinheiros pequenos, protegendo-os, deste modo, dos ventos e intempéries a que o litoral está mais sujeito.
Procedeu-se também à sementeira ou plantação de Acácias longifólias, nos intervalos dos regos, pois, tal como o estorno, são boas fixadoras de areias e, devido ao seu rápido desenvolvimento, fornecem protecção às árvores recém-nascidas.

Em consequência desta arborização, quando deflagrou o fogo de 1987, o estrato arbóreo das Dunas de Quiaios/Cantanhede/Mira era formado essencialmente por pinheiro bravo. Apesar destes povoamentos terem uma idade média compreendida entre 40 e 65 anos, no geral, os pinheiros apresentavamse pouco vigorosos, com diâmetros variáveis entre cerca de 15 e de $25 \mathrm{~cm}$ e com alturas médias de 4 a $6 \mathrm{~m}$ (X. VIEGAS, L. Lourenço, et al. 1987). Na área agora ardida, a situação era idêntica.

$O$ estrato arbustivo, fraco e heterogéneo, era predominantemente constituído por espécies características das areias litorais, tais como: camarinheira (Corema album), samouco (Myrica faia), tojo (Ulex sp), giesta (Cistus sp), Halimium alissoides, Lavandula sp e Juniperus phoenicia.

Toda esta vasta extensão se encontrava dividida em talhões de 32 e de 24 ha, respectivamente, nos PerímetrosFlorestais deQuiaios e de Mira-Cantanhede. Esses talhōes encontravam-se separados por aceiros transversais (W-E) e arrifes longitudinais (N-S), respectivamente, com 10 e $6 \mathrm{~m}$ de largura.

No entanto, na altura do incêndio, muitos dos caminhos encontravam-se invadidos por vegetação arbustiva, que, conjuntamente com os solos arenosos, terão dificultado o acesso, tanto às pessoas como aos meios motorizados empenhados no combate. A rede de estradas asfaltadas existentes na área é reduzida, não possibilitando o acesso a grande parte dos talhões. Além disso, os combustíveis encontravam-se distribuídos de forma bastante contínua, o que terá facilitado a progressão das chamas, acrescendo ainda o facto do pinheiro ser uma espécie resinosa, logo de maior susceptibilidade ao fogo, em virtude das substâncias inflamáveis presentes na sua constituição.

No que respeita à Serra da Boa Viagem, a primeira área a ser submetida ao regime florestal foi

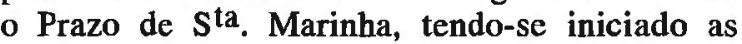
sementeiras e plantações em 1913, vindo a ser dadas como terminadas dez anos depois (M. A.REI, 1925). A principal espécie introduzida foi o pinheiro bravo (Pinus pinaster), mas como se tivesse observado a inadequação de alguns vales da Serra ao pinheiro bravo, procurou-se introduzir neles um conjunto de plantas exóticas, tais como abetos, acácias e eucaliptos, totalizando no conjunto 75 espécies diferentes (A. C. M. NoRA, 1993).

Dentro do Perímetro Florestal do Prazo de $S^{t a}$. Marinha, apesar da grande variedade de espécies introduzidas, podemos referir como espécies predominantes pinheiro bravo (Pinus pinaster), pinheiro 
manso (Pinus pinea), pinheiro de Alepo (Pinus halepensis), este especialmente na vertente ocidental da Serra, eucalipto (Eucaliptus globulus) e outros. O cedro do Buçaco (Cupressus lusitanicus) e diversas folhosas (faia, plátanos, choupos e outras) são espécies que também assumiam alguma importância. No total, existiam cerca de $78 \%$ de resinosas e, apenas, $22 \%$ de folhosas.

Como é sabido, as folhosas são árvores de crescimento lento, que se desenvolvem sobretudo em zonas de maior humidade. Geralmente tem folhas largas e perdem a sua folhagem no Outono. Devido às condições próprias em que crescem e ao microclima que criam, os incêndios propagam-se de forma mais lenta neste tipo de árvore do que nas resinosas.

Eucaliptos e acácias, apesar de folhosas, apresentam-se também bastante vulneráveis ao fogo, pois, na sua composição existem substâncias voláteis bastante inflamáveis, as quais libertam grande quantidade de energia ao arder, levando a que as chamas tenham tendência a aumentar a sua velocidade de propagação.

Quando ocorreu o fogo, muitas das árvores existentes na Serra da Boa Viagem encontravam-se decrépitas ou até mortas (A. C. M. NorA, 1993) e alguns dos povoamentos demonstravam necessidade de ser desbastados, devido à forte invasão de Acácias melanoxilon e outras que se encontravammais dispersas e que, na altura do fogo, revestiam quase totalmente a Serra.

Pouco a pouco, a Acácia melanoxilon foi-se transformando numa espécie com características de infestante, pois, a destruição encetada todos os anos veio a mostrar-se ineficaz. Outra invasora, que também assumia alguma importância, era a hera (Hedera helix), uma trepadeira que estava a colonizar com grande intensidade todo o Perímetro e a causar a morte de inúmeras árvores.

O coberto sub-arbustivo, distribuía-se de forma bastante heterogénea, formando pequenos núcleos dispersos, relacionados com o tipo de solo e respectiva capacidade de retenção de água.

Quando ocorreram os incêndios, tanto as matas da Serra da Boa Viagem como as das Dunas se encontravam, além de muito envelhecidas, recheadas de caruma, de pinhas e de muitos ramos secos, materiais finos que na presença de fogo, constituíam autênticos "barris de pólvora".

Além disso, em termos de rede viária, a que se desenvolve pela Serra, não sendo muito densa, é constituída por estradas amplas com cerca de $6 \mathrm{~m}$ de largura ecompletada por algumas "veredas" ecaminhos florestais, de terra batida, os quais, em muitas situações, se encontravam cobertos por uma vegetação rasteira. Apesar da existência desta rede viária, havia locais onde o acesso era difícil, senão impossível, pelo que com o tipo de combustível existente e com estes acessos, em certos sítios o combate directo às chamas era impensável.

\section{Situações meteorológicas que acompanharam os incêndios}

A observação das cartas sinópticas referentes ao dia 19 de Julho, data em que eclodiu o primeiro foco de incêndio nas Dunas de Mira/Cantanhede/ Quiaios mostram a Península Ibérica sob a influência de um anticiclone localizado sobre o arquipélago dos Açores, o qual determinava, no litoral, uma circulação de Norte.

Porém, a Sueste da Península começava a desenhar-se um centro de Baix as Pressões, o qual se foi intensificando e deslocando para NE, afectando o estado do tempo no dia seguinte, embora o vento, tivesse continuado a soprar do quadrante Norte, alternando com rumos de Noroeste.

A entrada de massas de ar com percurso marítimo permitiu que os valores mínimos da humidade relativa do ar se mantivessem elevados ao longo do dia $19 \mathrm{e}$ 20 de Julho, acima dos 50\%, enquanto que os da temperatura máxima do ar rondavam $26 \square \mathrm{C}$ (valores registados em Monte Real).

Deste modo, as condições meteorológicas não sendo especialmente favoráveis, também não eram impeditivas à eclosão e desenvol vimento de grandes incêndios florestais. No dia 19, o fogo eclodiu e, depois, no dia 20 reacendeu-se, quando o grau de risco era moderado e, como tal, havia condições para controlo inicial daquele que viria a transformar-se num dos incêndios mais extensos da Região Centro, o fogo das Dunas de Mira/Cantanhede/Quiaios.

No dia 21, as condições alteraram-se completamente. $O$ anticiclone passou a estender-se em crista sobre o Golfo de Biscaia, originando uma circulação de ENE. Sabemos que esta situação sinóptica é particularmente favorável tanto ao desencadeamento, como à propagação de grandes incêndios florestais (F. ReBelo, 1980; L. LouRenço, 1987), devido ao trajecto continental das massas de ar, o qual não só lhes reduz o teor de humidade relativa, mas também lhes aumenta a temperatura do ar.

Esta alteração no rumo dos ventos foi acompanhada pela subida dos valores da temperatura máxima do ar, que passou, em Monte Real, de 22 $\square$ C, no dia 20, para 26 $\square \mathrm{C}$, no dia 21, para 37 $\square \mathrm{C}$, nodia 22 e para $39 \square \mathrm{C}$ no dia 23 , regressando aos $24 \square \mathrm{C}$ no dia 24 , enquanto que o valor da humidade relativa mínima decrescia, dos $52 \%$, no dia 20 , para os $39 \%$, no dia 21 , chegando até aos $17 \%$, no dia 22 , ficando-se pelos $19 \%$ no dia 23 e regressando aos $55 \%$ no dia 24. Nunca, no Verão de 1993, a humidade relativa do ar atingiu valores tão reduzidose, por esse motivo, o grau de risco foi tão alto (Fig. 4). 
Apesar dos incêndios não terem eclodido nestas condições, como, entretanto, não tinham sido extintos, elas vieram, sem dúvida, intensificar as proporções devastadoras que posteriormente atingiram, prosseguindo a sua marcha incontrolável por mais dois dias, acompanhandoo agravamento da situação meteorológica, que culminou no dia 23 , quando defl agraram três incêndios no litoral algarvio, de que trataremos adiante. Todos estes incêndios foram controlados, acabando por ser extintos, tal como normalmente sucede nestas circunstâncias, quando se verificou uma alteração nas condições sinópticas.

Com efeito, no Boletim Meteorológico Diário, do Instituto de Meteorologia, é visível, na carta de superfície relativa às $00 \mathrm{~h}$ UTC do dia 23 de Julho, um núcleo depressionário em formação a SW do estreitode Gibraltar, que a essa hora aindanão influenciava o estado do tempo em Portugal Continental. Contudo, a sua lenta intensificação e progressiva deslocação ao longo do dia para Norte, faz com que pelas $12 \mathrm{~h} 00$ se localizasse a Sul do Algarve, posição que ainda possibilitou a eclosão de fogos no ocidente algarvio.

Este posicionamento determinava uma circulação geral predominantemente de Sueste, a qual empurrou os fogos em direcção ao mar e, no caso do Centro Litoral, também para áreas já antes incineradas.

Não só por este motivo, mas principalmente porque a depressão continuou a sua marcha para Norte e às $00.00 \mathrm{~h}$ do dia 24 de Julho já estava centrada sensivelmente a ocidente do Porto
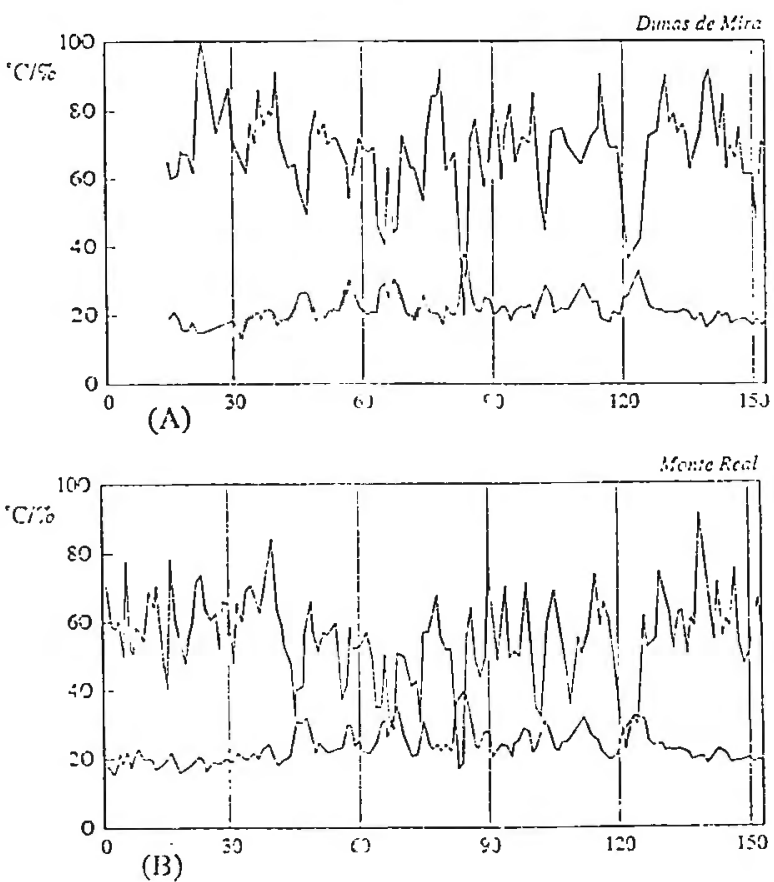

Fig. 4 - Evolução dos valores diários da temperatura máxima e da humidade relativa mínima do ar, durante a "época de fogos" de 1993, nas estações meteorologicas de Dunas de Mira (A) o Monte Real (B). determinando uma circulaçãode Sudoeste, com entrada de ar marítimo, mais húmido e fresco, todos os fogos puderam ser extintos durante o dia 24.

\section{Progressão dosincêndios das Dunas e da Serra - síntese comparativa}

Depois da descrição dos factos e das eventuais condições que contribuem para a sua explicação, vejamos agora, através de uma análise comparativa, comoé possivel relacionaros elementos antes descritos, procedendo à sua interpretação.

Observa-se que, em ambos os incêndios, houve uma fase bastante violenta (Fig. 5) ${ }^{1}$, a qual, no fogo das Dunas, terá decorrido sobretudo durante a madrugada do dia 23, altura em que a velocidade de progressão das chamas poderá ter superado $2,5 \mathrm{Km} /$ h. Seguiu-se-lhe um período em que o incêndio reduziu a sua marcha devastadora, continuando, no entanto, a propagar-se com grande velocidade até ao final da sua progressão.

De realçar que as velocidades máximas de progressão atingidas pelos incêndios, coincidem "grosso modo" com ventos de Leste. Esta situação vem, mais uma vez, confirmar que estes ventos, pelas suas características, são particularmente favoráveis à propagação de fogos florestais.

Deste modo, pelo facto de na área não existirem desníveis consideráveis, nem outros obstáculos maiores, somos levados a concluir que a velocidade de propagação do fogo foi determinada principalmente pela direcção e velocidade do vento. Com efeito, embora a fase de maior violência nãotenha coincidido com a de maior velocidade do vento, correspondeu a ventos que sopravam do quadrante Leste.

Nessa fase do incêndio, os combustíveis encontravam-se num elevado estado de secura e como se distribuíam homogeneamente à superfície, em especial a ocidente das Dunas de Quiaios, a rapidez de progressão das chamas viu-se facilitada, mesmo na ausência de ventos fortes. Com efeito, a própria energia libertada pela combustão dos materiais desencadeia correntes verticais ascendentes, ou seja, correntes de convecção resultantes da rápida ascensão do ar aquecido, as quais levam o ar frio a descer e a alimentar a combustão com ar fresco. Deste modo, as chamas podem aumentar grandemente de comprimento e intensificar a progressão do incêndio.

'Na construção dos histogramas com as velocidades médias dos dois incêndios foram tidos em conta dados conhecidos das horas e dos locais de passagem da frente principal dos incêndios. Convém, no entanto, salientar que estes valores devem ser tidos como aproximados devido a complexidade que caracterizou os incêndios, especialmente, o da Serra da Boa Viagem, sendo por isso muito difícil quantificar com exactidão a sua velocidade de progressão. 

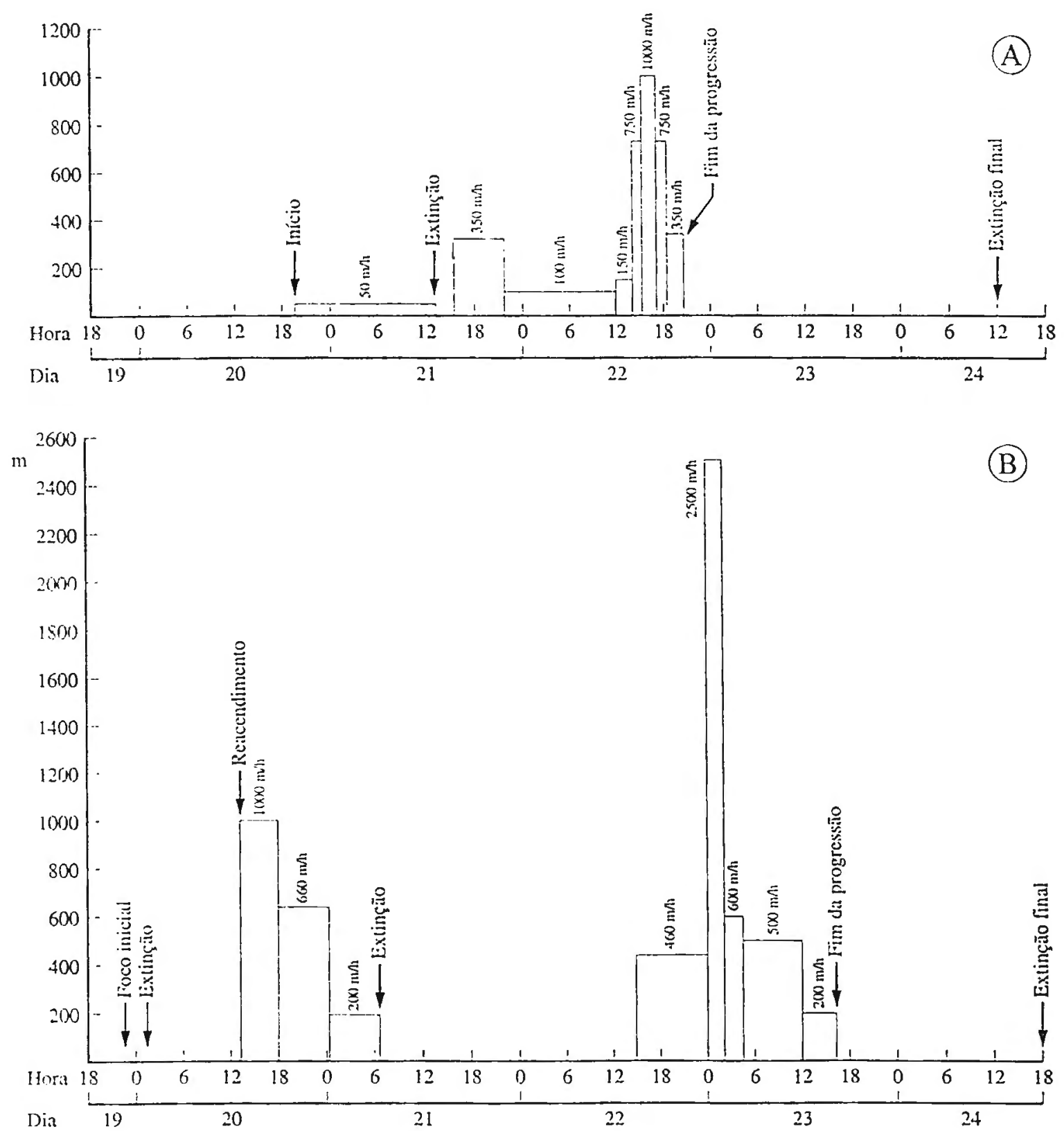

Fig. 5 - Represe ntação esquemática da velocidade de propagação das frentes de chamas ao longo das duas principais linhas de progressãe dos incèndios da Serra (A) e das Dunas (B).

Por outro lado, observou-se uma estreita correspondência entre a direcção do vento e a direcção de propagação das chamas. De maneira geral, a frente principal do fogo progredia sempre mais depressa quando era empurrada pelo vento que soprava nesse sentido. Nas zonas periféricas, a progressão fazia-se sempre com menor intensidade. A comprová-lo, está o facto de, nos dias 20 e 21, a progressão do incêndio ter sido claramente de Norte para Sul, visto que o rumo do vento era do quadrante Norte.

Durante esse período, a evolução do fogo limitou- se à parte situada a nascente da Estrada Florestal $n^{0} 1$ e só quando se registou um alteração no rumo do vento é que o incêndio transpôs essa via, passando a consumir a floresta da parte ocidental das Dunas. Nestas circunstâncias não restam dúvidas de que tanto a velocidade como a direcção de progressão do incêndio foram comandadas pelo vento. Aliás, foi também a sua mudança de direcção que permitiu o controlo e posterior extinção do fogo, não só pelo facto de terem entrado massas de ar mais fresco, mas também pelo "empurrar" das chamas primeiro em 
direcção ao mar e, depois, para áreas que já tinham sido, anteriormente, percorridas pelo incêndio.

No caso específico da Serra da Boa Viagem, a fase mais perigosa do incêndio ocorreu na tarde do dia 22, quando uma grande parte da Serra, designadamente o Prazo de $S^{\text {ta }}$. Marinha, foi consumida pelas chamas. Esta fase durou apenas entre 4 e 5 horas, ou seja, decorreu entre as 15 e as $20 \mathrm{~h}$, tendo correspondido à situação de maior violência, após a qual o incêndio, embora tivesse continuado no tempo, terminou praticamente a sua progressão à superfície. Deste modo, como antes da fase de propagação mais violenta, apesar da velocidade de progressão ter sido baixa, o incêndio não foi controlado e extinto, acabou por ficar incontrolável.

Uma análise mais pormenorizada mostra que, na Serra, a progressão do incêndio terá ocorrido de forma bastante diferenciada, podendo mesmo estabelecer-se duas fases distintas, ao longo do seu percurso.

A primeira, ocorreu nas noites de 20 para 21 e de 21 para 22 de Julho, quando o fogo avançava com uma velocidade pouco significativa. Algumas das razões que, eventualmente, poderão ser apontadas para a fraca intensidade das chamas nessa área relacionam-se com a inexistência de um coberto vegetal denso e contínuo e com a reduzida velocidade do vento durante a noite.

A segunda fase, coincidiu com a tarde do dia 22 , altura em que a velocidade de propagaçãose intensificou de tal forma que a vegetação da Serra ficou, na sua maior parte, destruída em apenas 4-5 horas.

A intensificação do fogo a partir do início da tarde do dia 22, fícou a dever-se à conjugação de diversos factores, nomeadamente ao forte declive das vertentes e ao vento, os quais terão facilitado a rápida ascensão do fogo e, ainda, às características e tipo de combustível. Com efeito, existiu uma coincidência entre a entrada do fogo na parte mais abrupta da Serra e o aumento da velocidade de propagação das chamas. Não restam pois dúvidas, de que o relevo, neste incêndio, assumiuuma função deveras importante.

Comoé sabido, ofogo progride mais rapidamente nas vertentes mais inclinadas, quando $\mathrm{cm}$ sentido ascendente, devido à aproximação das chamas aos combustiveis situados à frente e ligeiramente acima, facilitando, deste modo, o seu aquecimento e a sua rápida ignição (A. M. SARDINHA \& F. W. MACEDO, 1987). Por outro lado, os acentuados declives da vertente Norte da Serra impediam a mobilidade dos meios de combate, dificultando por esse motivo o ataque directo às chamas.

Além do relevo, também atribuímos um papel fundamental ao vento, especialmente em termos da intensidade de progressão do fogo, pois, não só se verificou um aumento de velocidade, mas também se registou uma mudança no rumo, tendo passado a soprar com uma componente de Leste. Como consequência desta alteração do rumo do vento, registou-se também um acréscimo do valor da temperatura e uma redução significativa dos valores da humidade relativa do ar, aumentando desta forma, ainda mais, as condições já de si propícias ao desenvolvimento do fogo.

Nestas circunstâncias, poder-se-á afirmar que a intensificação da progressão do incêndio da Serra se ficou a dever à conjugação dos seguintes factores: aumento da velocidade do vento, rotação do rumo do vento para Leste, aumento da temperatura do ar, diminuição da humidade relativa do ar e fortes declives.

A topografia ter-se-á revelado um factor fundamental na rápida progressão pois acentuou o efeito do vento e possibilitou que, nalguns locais, a projecção de materiais incandescentes tivesse levado ao aparecimento de novos focos de incêndio, os quais terão contribuido para dificultar o controlo do fogo.

Nestas circunstâncias, a propagação do fogo foi muito mais complexa na Serra do que nas Dunas, tendo-se efectuado com maior velocidade ao longo de duas linhas preferenciais, cujas frentes acabaram por contorná-la, quer pela parte ocidental, quer pela oriental (Fig. 2), vindo a criar as situações de maior violência durante o fogo.

O relevo foi o principal responsável pela forma que a progressão do fogo viria a tomar, pois afectou o regime local dos ventos, criando corredores preferenciais por onde sopraram com maior velocidade e ao longo dos quais a propagação das chamas se terá feito com mais intensidade, conferindo ao incêndio uma forma aproximada de ferradura.

De certomodo, esta forma resultou da deflecção que os ventos do quadrante Norte sofreram ao embaterem contra a Serra, acabando por se escoarem pelos seus flancos nascente e poente, gerando assim uma circulação contornante à volta do obstáculo que ela constituía.

Numa fase final, o desenvolvimento do fogo ter-se-á feito com várias frentes, algumas das quais acabariam mesmo por funcionar como contra-fogo final, tendo-se verificado o bem conhecido fenomeno de "efeito de chamada" que podemos definir como o efeito que uma frente do fogo exerce sobre a outra que está próxima dela. As correntes de convecção produzidas por ambas as frentes produzem uma acelaração mútua, de tal forma que o seu encontro se dá com grande violência e intensidade, além de que as características intrínsecas do relevo, pelas alterações que introduzem na circulaçãolocal, neste caso gerando circulação de retorno junto ao solo, também terão contribuído para acentuar este efeito (Fig. 3). No momento em que se deu o encontro das frentes houve um grande estrondo, segundo relatos de pessoas presentes, após o que o fogo praticamente se extinguiu, 
tendo, depois disso, continuado a lavrar de uma forma muito mais lenta.

Depois desta breve descrição da progressão do incêndio não restam dúvidas de que o vento assumiu um papel preponderante. Aliás, foi a mudança de rumo que transformou reacendimentos em frentes de chamas, mas foi também a mudança do rumo do vento que permitiu o controlo definitivo do fogo e a possibilidade de, no caso do das Dunas, o circunscrever a Sul, através de caminhos e aceiros, dado que no sentido Oeste aausência de combustivel e a proximidade do mar determinaram a sua extinção.

Contudo, como se observou pela velocidade de propagação do fogo parece-nos que teria sido possível controlar a sua progressão em diversos momentos, com particular destaque para as Estradas Nacional $n^{\circ} 335$ e Florestal $n^{\circ} 1$, o que, a ter-se verificado, reduziria significativamente os efeitos deste incêndio.

Além disso, a sua progressão resultou, não tanto dos focos iniciais, mas sim dos reacendimentos, comoaliás sucede na generalidade dos grandes incêndios, pelo que, por um lado, fica oalerta para a importância e necessidade de rescaldos e da vigilância após os fogos e, por outro lado, a premência em encarar os reacendimentos como verdadeiros fogos (o que nem sempre sucede), tanto mais que são eles os verdadeiros responsáveis pelos grandes incêndios florestais.

\section{Os incêndios do litoral ocidental algarvio}

Embora aparentemente fora do contexto geográfico dos incêndios anteriores, os fogos do litoral algarvio merecem-nos uma breve referência não só porque, como aqueles, ocorreram no litoral ocidental, mesmo junto ao mar e foram sensivelmente coincidentes no tempo, mas também porque geograficamente também se situaram muito próximos entre si, afectando uma área que, nosúltimos decénios, não tem sido varrida por incêndiose, fundamentalmente, porque se trata de uma Área de Paisagem Protegida, a do Sudoeste Alentejano e Costa Vicentina.

Por estes motivos, pareceu-nos ser útil efectuar uma breve sinopse comparativa com os incêndios do Centro Litoral, uma vez que, atendendo à distância, muitos aspectos não puderam ser analisados com o pormenor desejado.

\section{Os casos mais significativos}

\section{O incêndio de Alfambras (Aljezur)}

O fogo teve início no dia 23 de Julho, pelas 11:20 h, num local próximo do Monte Novo. Este incêndio só viria a ser dado como extinto no dia seguinte, depois de ter dizimado uma área aproximada de 1190 hectares (Fig. 6-B).
Como causa provável foi indicada a descarga de: faíscas provenientes de cabos eléctricos que, com o vento forte que se fazia sentir, se tocavam.

\section{O incêndio da Torre de Aspa (Vila do Bispo)}

O fogo também deflagrou no dia 23 de Julho, pelas 13:20 h, no interior do Perímetro Florestal de Vila do Bispo, tendo consumido cerca de 360 hectares de floresta e mato (Fig. 6-C).

A origem deste incêndio parece estar relacionada, comoodas Dunas de Mira, commateriaisem combustão provenientes da lixeira municipal, os quais, eventualmente, teriam sido arrastados pelo vento para os matos circundantes pegando-lhes fogo.

\section{O incêndio de Santa Susana (Aljezur)}

Também no dia 23 de Julho, pelas $14: 50 \mathrm{~h}$, deflagrou na área de Santa Susana outro foco de incêndio que progrediu em direcção ao Vale da Telha, tendo percorrido cerca de 2840 hectares de mato e floresta (Fig. 6-A).

Como o de Alfambras, este fogo também terá tido como origem provável, a descarga de faíscas oriundas de fios eléctricos que se tocavam em função do vento forte.

\section{Condições fisicas responsáveis pelo desenvolvimento dos fogos}

\section{Orografia}

A superfície culminante das áreas incineradas corresponde, em regra, a áreas aplanadas, situadas por volta dos $100 \mathrm{~m}$ de altitude, na qual se encaixam vigorosamente ribeiras e barrancos, em função do forte apelo exercido pela proximidade do nível de base. As vertentes apresentam-se, pois, com declives muito acentuados, o que certamente terá contribuído para dificultar o combate aos fogos.

\section{Cobertura vegetal}

A área florestal afectada por estes incêndios era essencialmente constituída por sobreiros, pinheiros, eucaliptos e acácias. Grande parte da mancha ardida era formada por matos de esteva, medronho, urzes e tojos. Foram ainda consumidas pelas chamas algumas áreas ocupadas por vinha $\mathrm{e}$ forragens.

A existência no solo de materiais combustíveis muito secos foi determinante para o alastramento dos focos iniciais.

Situações meteorológicas que acompanharam os incêndios

Condições meteorológicas de algum risco, caracterizadas por valores da temperatura do ar relativamente elevados, próximos dos $27 \square \mathrm{C}$, humidade relativa baixa, a rondar $30 \%$, e vento forte, com 

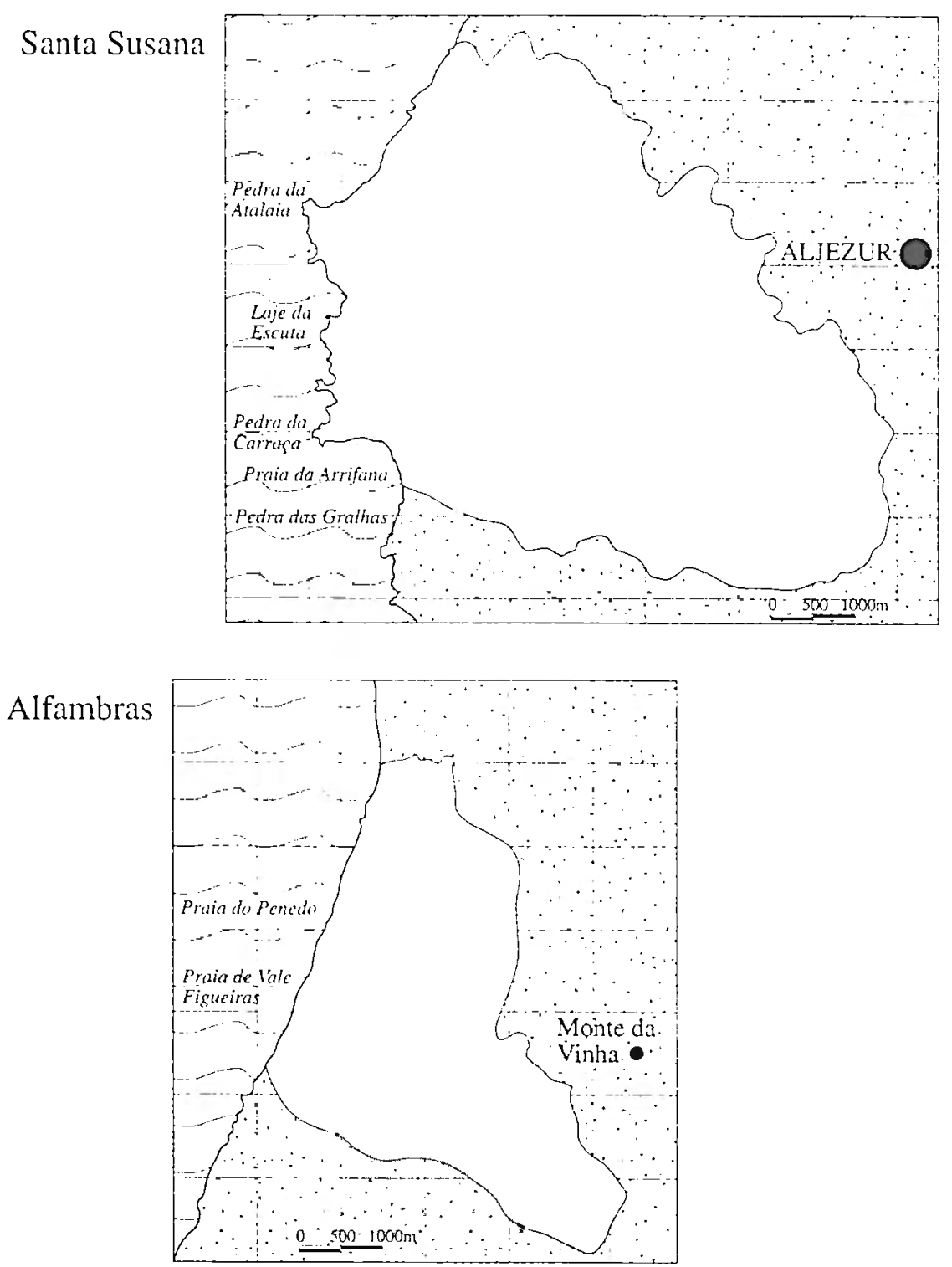

Torre de Aspa
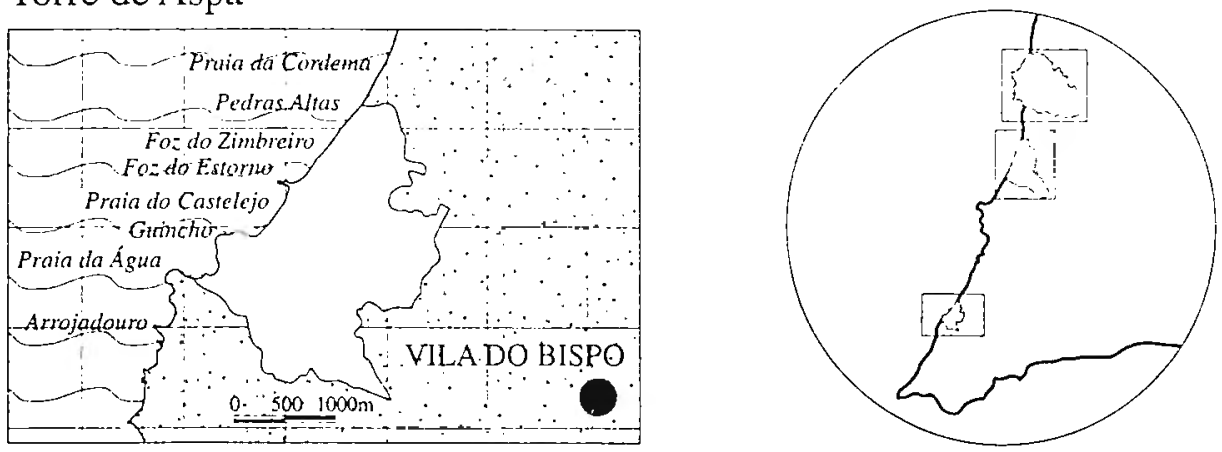

Fig. 6 - Esboço de localização dos incêndios do ocidente algarvio, em Julho de 1993: Santa Susana (A), Alfambras (B) e Torre de Aspa (C). 
velocidade da ordem dos $40 \mathrm{Km} / \mathrm{h}$ com rajadas que, por vezes, atingiram $80 \mathrm{Km} / \mathrm{h}$, foram factores decisivos para odesenvolvimento dos focos iniciais, transformando-os em incêndios de grandes proporções.

De certo modo, estes incêndios ficaram incontroláveis devido não só ao número de focos que, num curto espaço de tempo, deflagraram próximos uns dos outros, mas também ao pânico geradona população que obrigou à pulverização de esforços, prejudicando, por vezes, as acções de combate propriamente ditas.

\section{Observações e comentários}

Se, depois desta breve análise, ficámos com a sensação de que para os incêndios do litoral algarvio, atendendo ao conjunto das circunstâncias que os envolveram, dificilmente se poderia ter evitado a incineração de tantos hectares, no que concerne aos fogos do Centro Litoral, ficámos com a certeza de que se poderia ter evitado a incineração da maior parte da área ardida se tivessem existido certos procedimentos diferentes.

As observações e comentários que apresentamos a seguir não pretendem ser um julgamento. Devem ser entendidas apenas como críticas construtivas, com o único objectivo de esclarecer alguns aspectos quenosparecem tercontribuído para o desenvolvimento daqueles dois grandes incêndios, de modo a que possam ser introduzidas algumas melhorias no sistema tanto ao nível da análise do risco, como ao nível do desenvolvimento da crise (F. Rebelo, 1994), com vista a acções futuras.

\section{As lixeiras municipais como causa de deflagração de fogos}

O nosso primeiro comentário prende-se, naturalmente, com a origem dos fogos.

As estatísticas de incêndios florestais apontam as lixeiras municipais como uma das causas de fogos, responsabilizando-as pela destruição de várias dezenas de milhar de hectares de floresta.

Sabemos que, muitas vezes, a combustão não é provocada pelo pessoal das Câmaras Municipais nem seráda sua responsabilidade. Deve-se a sucateiros ou outros que nelas procuram materiais para utilização própria ou para venda, os quais são mais fáceis de procurar após a combustão do papel, plástico e outros desperdícios.

No entanto, as lixeiras municipais são causa de fogo florestal. Dos cinco casos de grandes incêndios florestais apresentados, dois deles foram devidos à existência de lixeiras municipais em combustão.

Inexplicavelmente, existe uma certa passividade, indiferença, diremos mesmo impunidade, perante determinadas situações causadoras de fogos florestais, de entre as quais destacamos as lixeiras municipais e que é urgente eliminar.

\section{Ausência de vigilância após orescaldo e de combate ass reacendimentos}

Os dois grandes incêndios do Centro Litoral tiveram origem, mais uma vez, no reacendimento de pequenos focos. Infelizmente, é uma situação que se repete com frequência, pelo que nos parece urgente e fundamental solucioná-la, o que poderá passar pela activação de Brigadas específicas para esse efeito, colaborando no rescaldo e permanecendo de vigilância no local durante algumas horas após a extinção do fogo.

O trabalho destas "Brigadas de Rescaldo e Vigilância" não se esgotaria no trabalho imediato a seguir ao fogo, pois deveriam ser utilizadas para outras actividades ligadas à prevenção, tais como, limpeza de bermas de estradas, sensibilização da população rural, patrulhamento de áreas florestais, etc.

Por outro lado, todos sabemos que os fogos se apagam mais facilmente enquanto são pequenos. Deste modo, énecessário privilegiar sempre o combate aos fogos nascentes, mesmo quando se trate de focos secundários ou de reacendimentos.

Com efeito, tanto focos secundários como reacendimentos, são responsáveis por grandes manchas ardidas, pelo que o combate a estes, enquanto nascentes, éuma necessidade imperiosa que tem de ser privilegiada.

\section{Dificuldades de penetração dos meios de combate,} desconhecimento do terreno, falta de coordenação

Tal como aconteceu no fogo das Dunas de Vagos/Mira em 1987 (X. VIEGAS, L. LouRENço etal., 1987), também nestes incêndios os Corpos de Bombeiros alegaram que uma das maiores dificuldades com que se debateram foi a inexistência de viaturas adequadas para progressão sobre areias, no caso do incêndio das Dunas, e os acessos difíceis, no caso da Serra da Boa Viagem. Estes factores terão contribuído para um atraso no combate inicial, de modo que, quando as Corporações chegaram aos locais do fogo, já as chamas alcançavam grandes proporções.

Poroutro lado, por parte das corporações presentes, no combate aos incêndios do concelho da Figueira da Foz, havia um certo desconhecimento da topografia dos locais onde deflagraram os focos de incêndio. A táctica então utilizada foi a de combater as chamas apenas quando estas se encontravam próximas dos caminhos florestais, ou de raras áreas mais para o interior, onde a natureza do solo permitia o avanço das viaturas.

Tratando-se de áreas públicas e estando também empenhados no combate Técnicos Florestais profundamente conhecedores da topografia e do combustível 
existente, custa-nos a entender que não se tenha gizado um único plano de combate aos fogos, envolvendo Bombeiros e Técnicos Florestais.

Apesar de ambas as entidades terem um objectivo comum, proteger a floresta, o que se verifica é que, muitas vezes, há uma falta de coordenação entre ambas, principalmente quando se trata de trabalharem juntas no terreno. Devido à falta de comunicação mútua, a inexistência dessa coordenação resultou num aproveitamento deficiente de todo o arsenal técnico e humano que foi disponibilizado para as frentes do fogo.

Além disso, verificou-se uma certa timidez ou falta de poder de decisão por parte de quem devia e tinha de decidir. E estas indecisões, na fase crucial do desenvolvimento dos incêndios, permitem que os pequenos focos se transformem em grandes incêndios. Para que tal não se verifique, é necessário que o Comando Operacional instaladono local tome decisões rápidas e precisas, baseadas no conhecimento da topografia, docombustível, das condições atmosféricas, da localização dos aglomerados populacionais, de casas de habitação isoladas, etc. e dos meios de combate de que dispõe, de modo a poder gerir e rentabilizar o esforço das forças disponíveis para 0 ataque ao fogo.

Se, mesmo assim, não for possível controlar o fogo, então, a nossa opinião é que se constitua um outro Comando Operacional, afastado do teatro de operações, não só para evitar o envolvimento emocional gerado pela proximidade do fogo, mas também, e sobretudo, parapoderrecorrer aoutro tipo de informação difícil de obter ou de tratar em instalações improvisadas.

Estes Comandos Operacionais, que nos parece deveriam ser implementados no futuro, seriam particularmente úteis quando lavram grande incêndios, em especial quando se localizam vários fogos grandes muito próximos uns dos outros, como, aliás sucedeu quer na Figueira da Foz, quer em Aljezur.

Muito sumariamente, pensamos que um Comando Operacional desta natureza deverá reunir obrigatoriamente representantes da Comissão Especializada de Fogos Florestais e técnicos de Serviço Nacional de Bombeiros edoInstituto Florestal. Além deles, poderia contar com a colaboração de elementos de outros serviços ou institutiçōes, bem como das autoridades policiais e de outros responsáveis que entendam dever envolver-se nos acontecimentos.

Parece-nos ser fundamental que, no mesmo edifício, se juntem todas as entidades que têm a ver com o fogo e que aí, em conjunto, tomem as decisões que entenderem adequadas às circunstâncias em causa.

Estes Centros de Coordenação Operacional de Grandes Incêndios Florestais deveriam funcionar preferencialmente num mesmoe único edifício comum ao Centro de Meios Aéreos e ao Centro de Prevenção e Detecção de Incêndios Florestais. Estes Centros teriam de dispor de documentos base, cartográficos e outros, pormenorizados, onde conste a topografia, o combustível, a evolução das situações sinópticas e das condições meteorológicas, a ditribuição do povoamento etc., com base nos quais se possa traçar um mapa com a representação da evolução das frentes de chamas e a localização dos meios de combate dispostos no terreno, de modo a permitirem uma visão conjunta do fogo, sempre actualizada e actualizável, ilustrando a sua contínua evolução. Seria em função destes elementos que se decidiria a táctica de combate a usar em cada uma das frentes de chamas.

Naturalmente que estes Centros estariam em contacto contínuo, via rádio, com os Comandantes dispostos no terreno, transmitindo-lhes as instruções necessárias para travar a progressão das frentes de chamas e deles recebendo indicações relativas à evolução dessa progressão.

Deste modo, criar-se-iam condições para se ter uma visão global do(s) incêndio(s) em tempo real e se poder efectuar uma "paragem" para reflexão e decisão, antes de se passar à acção, tão necessária para evitar decisões precipitadas, por vezes ineficazes, como já anteriormente foi relatado (X. VIEGAS, $L$. LOURENço et al., 1987, p. 39).

\section{Pontos críticos no combate}

As passagens da Estrada Nacional $n^{\circ} 335-1$ e da Florestal Florestal $n^{\circ} 1$

Como já foi referido, verificou-se uma certa tendência para combater o fogo das Dunas junto aos caminhos, devido ao desconhecimento e dificuldades de acesso ao interior das matas. Deste modo, os meios de combate deveriam estar dispostos ao longo das estradas, actuando em função e de acordo com as características do fogo, de modo a evitar que ele atravessasse as estradas. Seguindo esta lógica, como explicar, então, a transposição pelo fogo da Estrada dos Estreitos (EN n ${ }^{\circ} 335-1$ ), quando nessa área se encontrava instalado o Comando Operacional? Essa via tem uma largura considerável e possui faixas laterais de protecção que no total perfazem uma largura de aproximadamente $30 \mathrm{~m}$.

Quando se questionam as entidades presentes no combate ao fogo, as respostas relacionam-se sempre com as condições naturais. $O$ vento atingia, nessa altura, velocidades muito importantes e mudaria frequentemente de direcção. No entanto, embora admitamos uma vez ou outra essa possibilidade, não encontrámos registos que no local permitissem confirmar estes argumentos, sempre repetidos nestas circunstâncias.

Apesar de, durante a "época de fogos", procedermos ao cálculo da tendência do índice de 
risco de incêndio florestal para o dia seguinte (L. LOURENÇo, 1991 e 1994), muitas vezes, a sua divulgação não chega aos operacionais que no terreno combatem o fogo, pelo que nos parece fundamental que os Comandos Operacionais sejam dotados de equipamento meteorológico portátil que lhes permita avaliar a temperatura e humidade relativa do ar, bem como a direç̧ão e velocidade do vento, de acordo com o previsto no $\mathrm{n}^{0} 7$ do $\operatorname{art}^{\circ} 17$, do Dec. Reg. $\mathrm{n}^{\circ}$ 55/81.

Assim, seria possível conhecer com precisão as condições meteorológicas que, localmente, acompanham o desenvolvimento dos grandes incêndios, fundamentando ou não os actuais considerandos teóricos.

Os combustíveis, além de envelhecidos, encontravam-se muito secos, mas também não eram muito densos junto ao solo, pelo que o fogo progredia essencialmente por copas, facilitando a passagem da estrada.

No entanto, torna-se-nos difícil aceitar argumentos só de natureza física. É que os largos corredores que ladeavam a estrada encontravam-se despidos de vegetação e, só por si, constituiam uma barreira natural à progressão das chamas. Deste modo, deveriam ter sido aproveitados para controlar o incêndio, eventualmente, com recurso a contra-fogo, se tivesse havido uma visão conjunta e atempada da progressão do fogo, a qual, por não ter existido, se reflectiu numa certa falta de coordenação e consequente ineficácia dos meios disponíveis.

Se esta frente, a mais perigosa, porque avançava com maior velocidade e intensidade em função do rumo do vento, tivesse sido controlada naEN 335-1, depois teria sido possível deslocar meios para a Estrada Florestal $\mathrm{n}^{\circ} 1 \mathrm{e}$ aí controlar também o incêndio, tanto mais que a sua intensidade era relativamente fraca.

Se tal tivesse acontecido, seria mais um fogo sem história e os seus efeitos teriam sido bem menos nefastos.

A progressão do incêndio na Serra da Boa Viagem Outro aspecto, que também denota uma descoordenação entre os Serviços Florestais e os Corpos de Bombeiros, relaciona-se com a progressão do incêndio na Serra da Boa Viagem.

Com efeito, durante os dias 20, 21 e manhã do dia 22, a propagação das chamas fez-se com uma velocidade muito reduzida, entre 50 e $100 \mathrm{~m} / \mathrm{h}$. E, pois, difícil de compreender a razão pela qual não foram tomadas as devidas precauções, numa tentativa de controlo definitivo do incêndio, até porque, nessa altura, o fogo das Dunas encontrava-se numa fase de relativa acalmia e, ainda, muito afastado das Dunas de Quiaios, ou seja, do concelho da Figueira da Foz. Neste contexto, os meios humanos e técnicos deveriam ter sido mobilizados para as frentes do fogo, a fim de evitarem que ele entrasse na parte mais abrupta da vertenteNorte da serra, onde, naturalmente, assumiria proporções devastadoras e ficaria incontrolável.

Custa realmente a entender como um fogo que, pelas suas características, parecia "pedir que o apagassem" se veio a transformar num braseiro infernal que destruiu o rico e diversificado património florestal da Serra da Boa Viagem (Fot. 2).

Deste modo, além de rescaldos pouco eficazes dos focos iniciais, parece ter-se verificado também uma certa descoordenação no comando das operações, a qual motivou alguma ineficácia na actuação dos meios de combate envolvidos. 


\section{$A$ "nuvem" de fumo que cobriu Coimbra na tarde do dia 23}

Uma triste lembrança que resta na memória dos conimbricenses que não assistiram pessoalmente ao desaparecimento de uma das mais vastas extensões de pinhal do litoral português, para além de toda a informação veiculada através dos meios de comunicação social, é a da "nuvem" de fumo, que cobriu a área circundante aos concelhos onde deflagraram os incêndios e que acabou por alcançar Coimbra, situada a cerca de quatro dezenas de quilómetros das áreas incineradas, que ficou envolta numa vasta "nuvem" de fumo.

Com efeito, as elevadas proporções alcançadas pelos incêndios do Centro Litoral, fizeram com que, na tarde do dia 23, tanto a Figueira da Foz como as áreas vizinhas ficassem envoltas numa densa "nuvem" de fumo e de fagulhas apagadas. A visibilidade, nas ruas da cidade da Figueira, era apenas de escassos metros.

A alteração do rumo do vento, que pelas 15:00 $\mathrm{h}$ passou a soprar de Oeste, fez com que a coluna de fumo fosse lentamente empurrada sobre a vasta planicíe do Mondego tendo atingido Coimbra pelo fim da tarde, entre as 18:00 e as 19:00 h. A sua chegada, sob a forma de um manto de nevoeiro denso e escuro, foi impressionante obrigando os automobilistas a circularem de faróis acesos. Às 20:00 h, ainda a cidade se encontrava invadida por essa espessa camada de fumo, que só se dissipou algumas horas depois.

As pessoas, alarmadas com tal quantidade de fumo, fizeram inúmeros telefonemas para os Corpos de B ombeiros, procurando saber o que se passava ou dando conhecimento do fumo e, até, de supostos focos de incêndio que não passavam de falsos alarmes, ao ponto do Serviço Distrital de Protecção Civil ter recorrido às emissões locais e regionais de rádio, não só para esclarecer a população sobre a origem do fumo, mas também para lhe solicitar que não efectuasse mais telefonemas para os Bombeiros, cuja rede telefónica se encontrava perfeitamente saturada.

Deste modo, os efeitos dos incêndios não se circunscreveram apenas às áreas incineradas, nem envolveram apenas os meios técnicos e humanos directamente empenhados no combate, mas afectaram uma area muito mais vasta e perduraram por muito mais tempo do que aquelas cerca de 90 horas em que as matas foram dizimadas.

\section{Conclusão}

Sabemos que, felizmente, apenas cerca de $1 \%$ dos fogos florestais alcançam grandes proporções e também sabemos que apenas esses são responsáveis pela quase totalidade das manchas ardidas, pelo que importa analisá-los, de modo a evitar-se a sua repetição.

Do acompanhamento de grandes incêndios ocorridos em anos anteriores, bem como do estudo agora efectuado, sobretudo noque respeita aos incêndios do Centro Litoral, ressaltou a necessidade da entrada em funcionamento de duas novas estruturas, as Brigadas de Rescaldo e Vigilância após o Fogo e os Centros de Comando Operacional dos Grandes Incêndios Florestais, a funcionarem afastados das áreas que estão a ser pasto das chamas. A criação destas novas estruturas poderá, perfeitamente, passar pela reorganização ou adaptação de estruturas já existentes.

Se, na sequência dos grandes fogos florestais do Litoral português do ano de 1993, estas medidas viessem a ser implementadas, talvez aqueles não ficassem na nossa memória só pelos seus efeitos negativos, mas também por terem contribuído para que, nos anos seguintes, se registasse uma importante diminuição dos grandes fogos florestais.

\section{Agradecimento}

Os autores manifestamo seuvivo reconhecimento à Comissão Nacional Especializada de Fogos Florestais pelo apoio dado à investigação destes incêndios e aos responsáveis e técnicos do Instituto Florestal, da Delegação Florestal da Beira Litoral, das Zonas Florestais do Baixo Mondegoe do Barlavento Algarvio, da ex-Administração Florestal de Mira, do Serviço Nacional de Bombeiros, da Inspecção Regional de Bombeiros do Centro, dos Corpos de Bombeiros de Mira, Figueira da Foz e Aljezur e do Instituto de Conservação da Natureza, Área de Paisagem Protegida doSudoeste Alentejanoe Costa Vicentina. Agradecem as prestimosas informações e elementos que lhes forneceram, sem os quais seria impensável realizar este trabalho.

A todos osoutros que, anonimamente, colaboraram para a concretização desta tarefa, deixamos aqui expressa a nossa gratidão.

\section{BIBLIOGRAFIA}

A lmeida A. Campar de (1990) - “ Os solos na paisagem das dunas de Quiaios". Cadernos de Geografia, Coimbra, 9, p. 151-162;

LOURENÇO, L. (1988) - "Tipos de tempo correspondentes aos grandes incêndios florestais ocorridosem 1986 no Centro de Portugal". Finisterra, Lisboa, 23 (46), p. 251-270;

LOURENço, L. (1990) - "Impacte ambiental dos incên dios florestais". Cadernos de Geografia, Coimbra, 9, p. 143-150;

LOUREnço, L. (1991) - "Uma fórmula expedita para determinar o índice meteorológico de risco de eclosão de fogos florestais 
em Portugal Continental". Cadernos Cientificos sobre Incêndtios Florestais, Coimbra, 2, p. 3-63;

Lourenço, L. (1992) - "Avaliação do risco de incêndio nas matas e florestas de Portugal Continental". Finisterra, Lisboa, 27 (5354), p. 115-140;

Lourenço, L. (1994) - "Risco de incêndio florestal em Portugal Continental". Informação Florestal, 4, p.22-32;

Ministérios da Defesa Nacional, da Administração Interna e da Agricultura, Comércioe Pescas (1981)-DecretoRegulamentar $\mathrm{n}^{\circ} 55$ de 18 de Dezembro. Diário da República, 1 Série, $\mathrm{n}^{\circ} 290$, p. 3299-3307.

Nora, A. C. M., (1993) - "Projecto de valorizaçāo dos recursos da Serra da Boa Viagem-Perímetro florestal do Prazo de Santa Marinha", Relatório final de estágio.

N LNES, A. (1994a) - “Progressão do Fogo na Serra da Boa Viagem”. Viagem de Estudo, Livro Guia da Viagem de estudo ao Baixo Mondego e dunas litorais, II Eprif, Coimbra, 23 de Fevereiro de 1994, p.45-49.

Nines, A. (1994b) - "Progressão do Fogo nas Dunas de Mira/ Cantanhede/Quiaios", Viagem de estudo.Livro Guja da Viagem de estudo ao Baixo Mondegoe dunas litorais, II Eprif, Coimbra, 23 de Fevereiro de 1994, p.71-75.

Nunes, A. (1994c) - O incêndio da Serra da Boa Viagem e o das Dunas de Mira/CantanhedelQuiaios - Julho de 1993 - Análise Comparativa- Relatório de Seminário de Geografia Física, Coimbra, 59 p. (inédito)

REBELo, F. (1980) - "Condiçð̌es de tempo favoráveis à ocorrência de incêndios florestais. Análise dos dados referentes a Julho e Agosto de 1975 na área de Coimbra". Biblos, Coimbra, 56, p.653-673.

Rebelo, F. (1994) - "Risco e Crise. Grandes incêndios florestais".
Actas, II Eprif, Coimbra, 21 a 23 de Fevereiro de 1994, p. 19-32.

Rebelo, F.; Clinha, L; Almeida, A. C. (1990) - " Contribuição da Geografia Física para a inventariação das potencialidades turísticas do Baixo Mondego". Cadernos de Geografia, Coimbra, 9, p. 3-34.

Rel, M. A.(1924) - Pinhais e Dunas de Mira. Figueira da Foz.

REr, M. A. (1925) - "Arborizaçāo da Serra da Boa Viagem da Figueira da Foz-" Subsídios para a sua história, 1911-1924. Figueira da Foz.

Sardinha, A. M.; Macedo, F. W. (1987) - "Fogos Florestais", Lisboa, Publicações Ciência e Vida.

Viegas D. X.; Lourenço, L; Neto L.; P Ais T.; Reis J. \& Ferreira A. (1987) - Análise do incêndio florestal ocorrido em Vagos/ Mira, de 27 a 29 de Julho de 1987. Centro de Mecânica dos Fluidos, Coimbra, 46 p. +1 mapa.

\section{Relatórios inéditos:}

Fogo Florestal na Figueira da Foz em 93/07/20, IRBC, Coimbra.

Fogo Florestal das Dunas de Mira, Tocha e Quiaios, 1993, DFBL, Coimbra.

Incêndio nas Dunas de Mira, Dunas de Cantanhede, Dunas de Quiaios e Serra da Boa Viagem. 1993, CPDI, Lousã.

Estatística de Incêndios Florestais do Concelho de Aljezur, 1993, ZFB, Portimão.

Relatório sobre os incêndios ocorridos na A.P.P.S.A.C. V.,1993, ICN, Aljezur.

Valores da temperatura do ar, da humidade relativa, quantidade de precipitação, direç̧ão e velocidade do vento, das estações meteorológicas de Dunas de Mira e Monchique, 1993, IM, Lisboa.

Valores da temperatura do ar, da humidade relativa, quantidade deprecipitação, direç̧ão e velocidade do vento, da estaçāo meteorológica de Monte Real, 1993, FAP, Monte Real. 
